$16^{\text {th }}$ International Conference on

AEROSPACE SCIENCES \& AVIATION TECHNOLOGY,

$\boldsymbol{A S A T}$ - 16 - May 26 - 28, 2015, E-Mail: asat@mtc.edu.eg

Military Technical College, Kobry Elkobbah, Cairo, Egypt

Tel : +(202) 24025292 - 24036138, Fax: +(202) 22621908

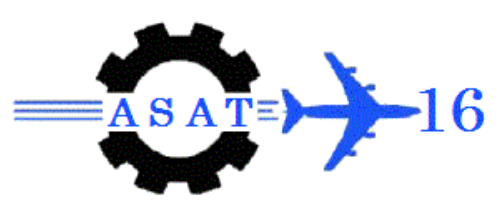

\title{
Effect of Stator Shape on the Performance of Torque Converter
}

\author{
\{A. Khafagy ${ }^{*}$, I. Saleh 'I. Elsherief $\}^{\dagger}$
}

\begin{abstract}
Torque converter is an enclosed hydrodynamic turbomachine, used in vehicles for smooth transmission of power and speed change from the engine to the transmission and torque multiplication. Torque converter consists of three major components: a pump that is connected to the engine shaft, a turbine connected to the transmission shaft, and a stator connected to transmission housing through a one-way clutch. Stator blades provide a guiding for the fluid flow. Stator is a main factor in controlling the torque ratio, pressure distribution and coupling point speed ratio. In this paper, the effects of the stator blade shape on overall performance have been investigated numerically at different speed ratios, using commercial software, ANSYS-CFX. Two torque converters with two different stator blade shapes are used for this study. The first stator has a large round nose, while the second stator is a thinner blade stator. At high speed ratio there is more blockage to flow of large inlet radius stator. Results showed that torque converter with thin blade resulted in an increase of torque ratio at fixed turbine and maximum efficiency. The bending of the thin blade caused a blockage to fluid flow.
\end{abstract}

KEYWORDS: Computational Fluid Dynamics (CFD), Torque Converter.

khafagy@gmail.com

$\dagger \quad$ Egyptian Armed Forces, Egypt. 


\section{Introduction}

An automotive torque converter, as shown in Figure 1, is a complex turbomachine used to transfer power from a vehicle engine to its transmission. It also multiplies the engine torque at a low engine speed, which improves a vehicle launching performance. Torque converter keeps an engine rotating at an idling speed without a need of clutch and also reduces rotational disturbances at a low engine speed. Detailed description of torque converter components, performance and operation are explained in detailed by Khafagy et. al. [1].

To improve the performance of a torque converter it is necessary to understand the flow field inside it. In the last few years, Computational Fluid Dynamics (CFD) played an important role in understanding the flow inside torque converters with the improved commercial CFD codes and high computational resources. In this paper the flow inside two different torque converters was studied using CFD code ANSYS-CFX at different operating conditions. A numerical simulation are carried out to provide a detailed fluid flow in two torque converter with the same size and different stator blade shape. The Allison-335 torque converter with two different stator are used for this study. The first stator has a large round nose, while the second stator is a thinner blade stator. The first stator blade shape considered in this investigation contains a curved nose at the stator inlet that acting as accelerating and smoothing the flow into the stator. Figure 2 shows the stator blade mesh for Allison-335 torque converter. A cross section of the stator blade is shown in Figure 3. This torque converter will be denoted as Allison-335. Figure 4 shows the suggested thin stator blade mesh, while Figure 5 shows the thin stator blade cross section. This torque converter will be denoted as stator thin. Table 1 shows the number of blades in the two torque converters.

Table 1: Number of blades of the two torque converters

\begin{tabular}{|c|c|}
\hline Allison $335 \mathrm{~mm} /$ stator thin \\
\hline Element & No of blades \\
\hline Pump & 20 \\
\hline Turbine & 23 \\
\hline Stator & 22 \\
\hline
\end{tabular}

\section{Literature Work.}

A number of researches have studied the flow features in a torque converter employing numerical and experimental methods. By and Lakshminarayana [2,3] measured average static pressure on the blades of the torque converter pump and turbine. Their results showed that the primary factor responsible for the static pressure rise in the pump is the centrifugal force and the static pressure distribution is generally poor at the blade core section. Brun and Flack [4] employed a laser velocimetry in a Plexiglas torque converter to obtain detailed velocity profiles inside torque converter turbine. They presented flow data of a torque converter at speed ratio of 0.065 and 0.8 .

Fujitaniet. al.[5] computed the flow within a torque converter by assuming that the inlet boundary condition of each element is equivalent to the outlet boundary condition of the upstream-side element. Abe et. al.[6] conducted numerical analysis of the flow field by adopting the steady-interaction technique to connect the boundaries between the neighboring elements. They did not include a turbulence model. By et al. [7] developed a three dimensional, incompressible, viscous flow code to predict the flow field in a torque converter pump using the pseudo-compressibility method. They analyzed the secondary flow patterns in the pump and compared them with experimental results. Cigarini and Sreenadh[8] performed a three dimensional simulation of the fluid flow in an automotive torque converter by applying steady interaction technique implemented in the CFD program STAR-CD. They 
used the standard k- $\varepsilon$ turbulence model in their analysis. The torque ratio showed a good agreement when compared with the experimental data. They concluded that the used code can simulate the fluid flow with sufficient accuracy. Dong et. al. [9] conducted CFD simulation to develop new stators to increase torque ratio at turbine speed equal zero and $\mathrm{K}$-factor improvement. The results showed that there is an increase in the stall torque ratio for newly developed torque converter. They concluded that the main reasons for this increase in torque ratio were the increased stator exit angle and decreased stator losses. Schweitzer and Gandham[10]had described some of the work done to validate CFD results and gave examples of ways in which CFD is used in the torque converter design process. Based on the validation studies, they concluded that CFD could be used as a design and analysis tool for torque converter development.

The literature reveals the need for flow field analysis in improving the design and performance of a torque converter. Due to the complex structure, very few computational studies have been reported previously and since these are performed by car manufactures, the detailed flow investigations results are not published. In the present work, numerical simulation are carried out to provide a detailed fluid flow in two torque converter.

\section{The Numerical Model.}

The commercial code ANSYS-CFX is a Finite Volume based CFD package with second order accuracy and an algebraic multi-grid technique. ANSYS-CFX is an integrated software system capable of solving diverse and complex three-dimensional fluid flow problems. The software uses unstructured and block-structured non-orthogonal grids with grid embedding and grid attaching to discretize the domain.

The boundary conditions were specified at CFX-Pre. The Multiple Reference Frame technique was used to model the torque converter elements that are rotating relative to one another. The fluid is defined as Automatic Transmission Fluid (ATF). The fluid is incompressible with constant physical properties with density of $(816) \mathrm{kg} / \mathrm{m}^{3}$, and viscosity of $(0.0024) \mathrm{N} \mathrm{s} / \mathrm{m}^{2}$ at temperature of $60^{\circ} \mathrm{C}$. The numerical analysis used the standard $\mathrm{k}-\varepsilon$ model for turbulence. The first order upwind scheme was used for discretization between the inlet and outlet. The residual were converged to a minimum of 1.0 E-4.

All simulations were run using stage averaging between the torque converter elements to obtain steady state solutions. The effect of grid density on the numerical results was investigated.

The flow field inside a torque converter was simulated under three different speed ratios (stall, design point and near the coupling point). The pump of the torque converter was assigned a constant speed of $1000 \mathrm{rpm}$.

The calculated torque is the integral of the pressure over the element blade. The pump torque added to the stator torque is examined to be equal to the turbine torque. Also, the mass flow rate outputted from each element is examined to be equal the next element flow rate.

\section{Grid Size Effect}

The effect of grid size on CFD results is presented in Figure 6 and Figure 7 for Allison-335 torque converter. Figure 6 shows the variation of pump torque against the number of grid elements. Figure 7 shows the variation of torque ratio against the number of grid elements. Figure 6 and Figure 7 show that the calculated pump torque and torque ratio is the same for medium and fine grid sizes. This indicates that the CFD results are not sensitive to the change in the grid size. The medium size grid is used for Allison-335 torque converter. 


\section{Results and Discussion}

The pump torque for both stator shapes is shown in Figure 8. The Allison-335 pump torque is higher than the torque converter with thin blade.

The turbine torque for different stator shapes is higher for Allison-335 stator for all speed ratios as shown in Figure 9.

Figure 10 shows a comparison between the torque ratio for the two torque converters. Although the pump and turbine torque is higher for Allison-335 torque converter the torque ratio is increased by about $15 \%$ at speed ratio zero. Figure 11 shows that the efficiency of the torque converter with thin stator is higher than the efficiency of Allison-335 torque converter. The maximum efficiency is increased from about $75 \%$ to $80 \%$.

Figure 12 shows that the pump head is lower for the torque converter with thin blade stator. Figure 13 shows that the turbine head is slightly lower for the thin blade stator torque converter. The head difference (pump head - turbine head) is lower for torque converter with thin blade as shown in Figure 14. Figure 15 shows that the flow rate across torque converter with thin blade stator is lower than Allison-335 torque converter. That is because the area at exit of the thin blade stator is much smaller than the inlet area, (as shown in Figure 5).

Figure 16 to Figure 19 show the pressure distribution along a streamline midway between hub and shroud inside the two torque converters at different speed ratios. These figures show that stator blade shape affects the pressure distribution inside torque converters. Also, it show that the pressure inside torque converter with thin stator blade is lower than Allison-335 torque converter for all speed ratios. The minimum pressure inside the stator is very low which means that cavitation may happen inside the torque converter with stator thin blade shape specially at low speed ratios. Guide vanes (torque converter stator) are designed in convergeddiverged sectional shape in order to increase the pressure at the pump entrance.

\section{Conclusions}

Numerical investigation of the flow field inside two torque converters was presented to study the effect of stator blades shape on torque converter performance.

Stator blade shape and thickness decreases the torque converter elements torque, increases the torque ratio, increases the maximum efficiency, causes a minor effect on the coupling point and decreases the minimum pressure (and hence the probability of cavitation). The pressure distribution inside the turbine flow path is increased at fixed turbine. 


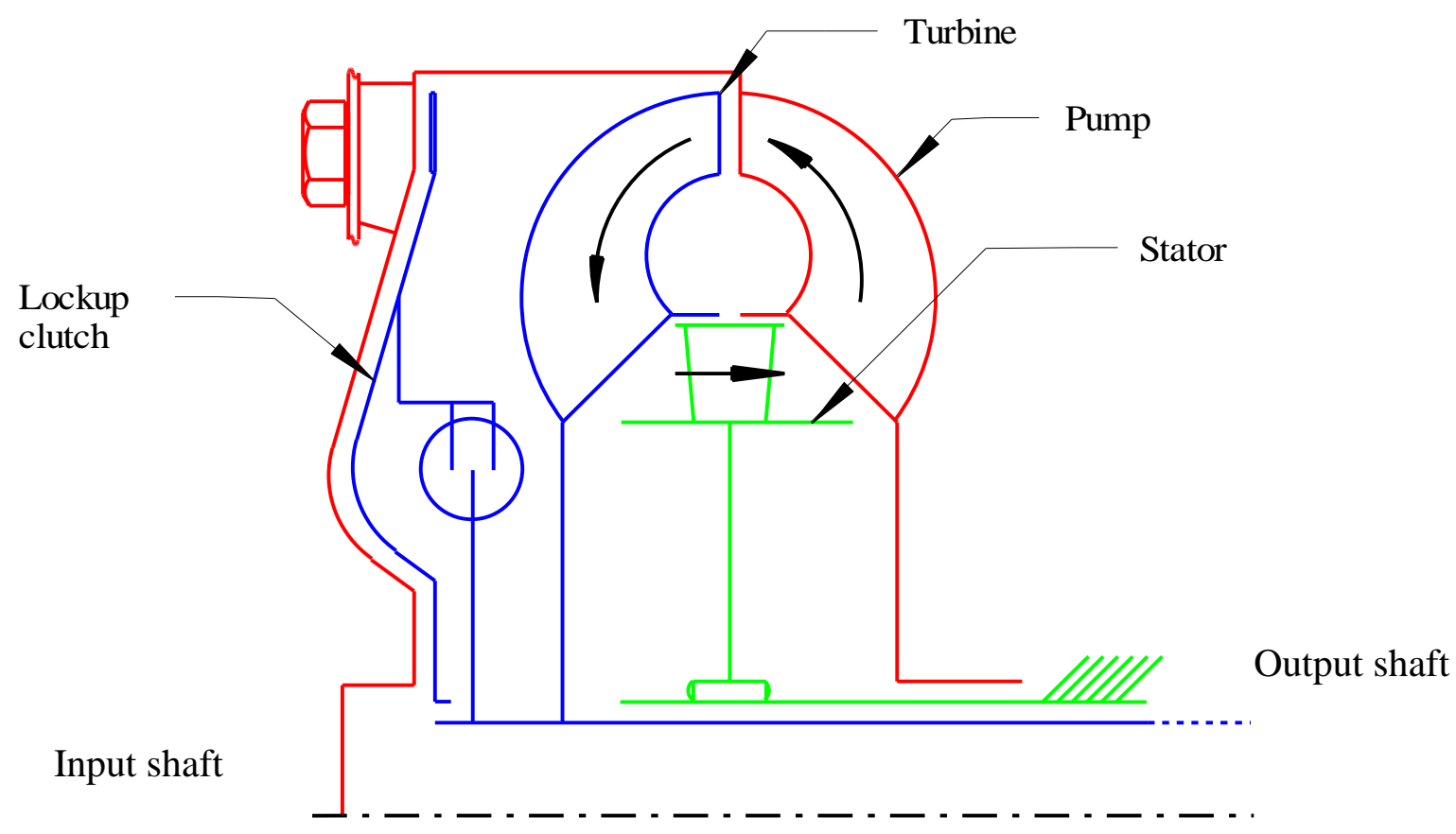

Figure 1: Schematic cross section of a torque converter

\section{ANSTYS}
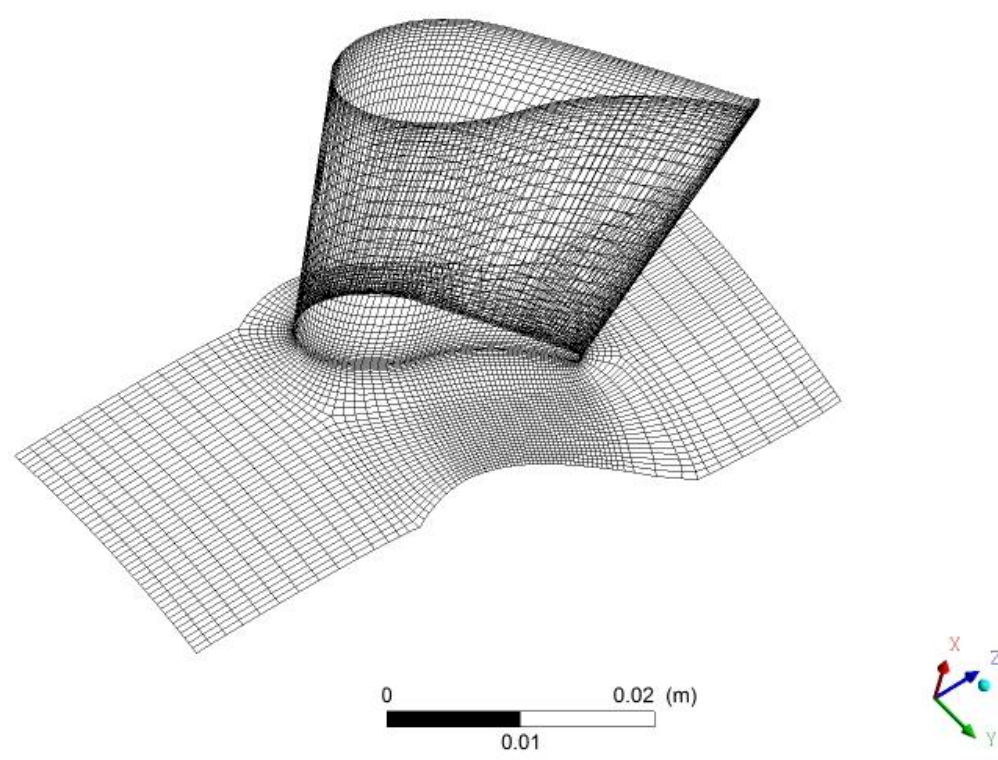

Figure 2: Allison-335 stator blade mesh 


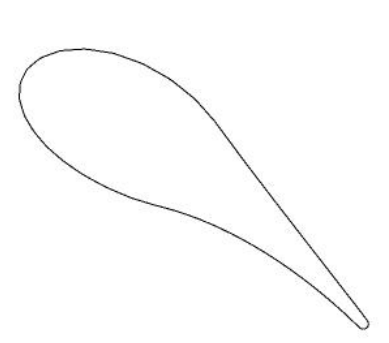

ANSTYS

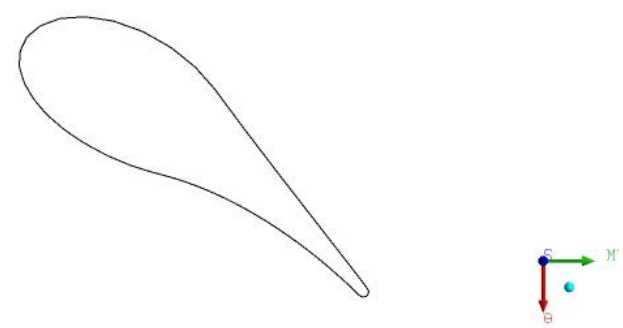

Figure 3:

stator

blade

cross

section
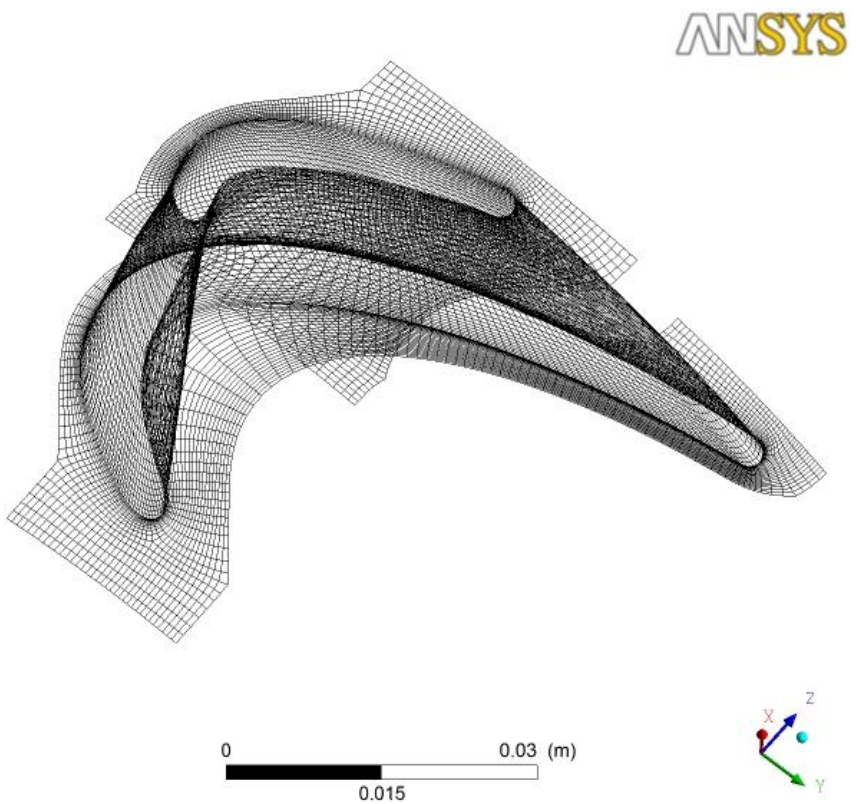

Figure 4: Stator thin blade mesh

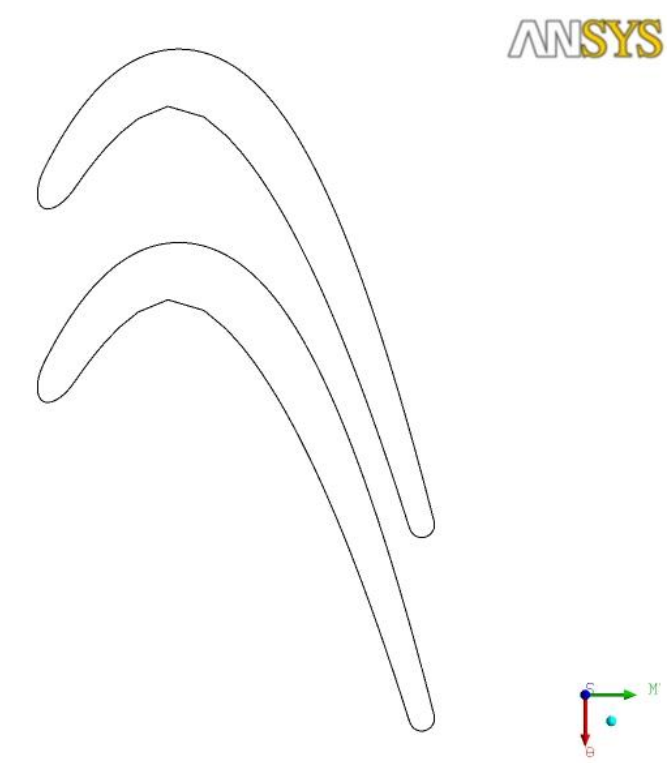

Figure 5: Stator thin blade cross section 


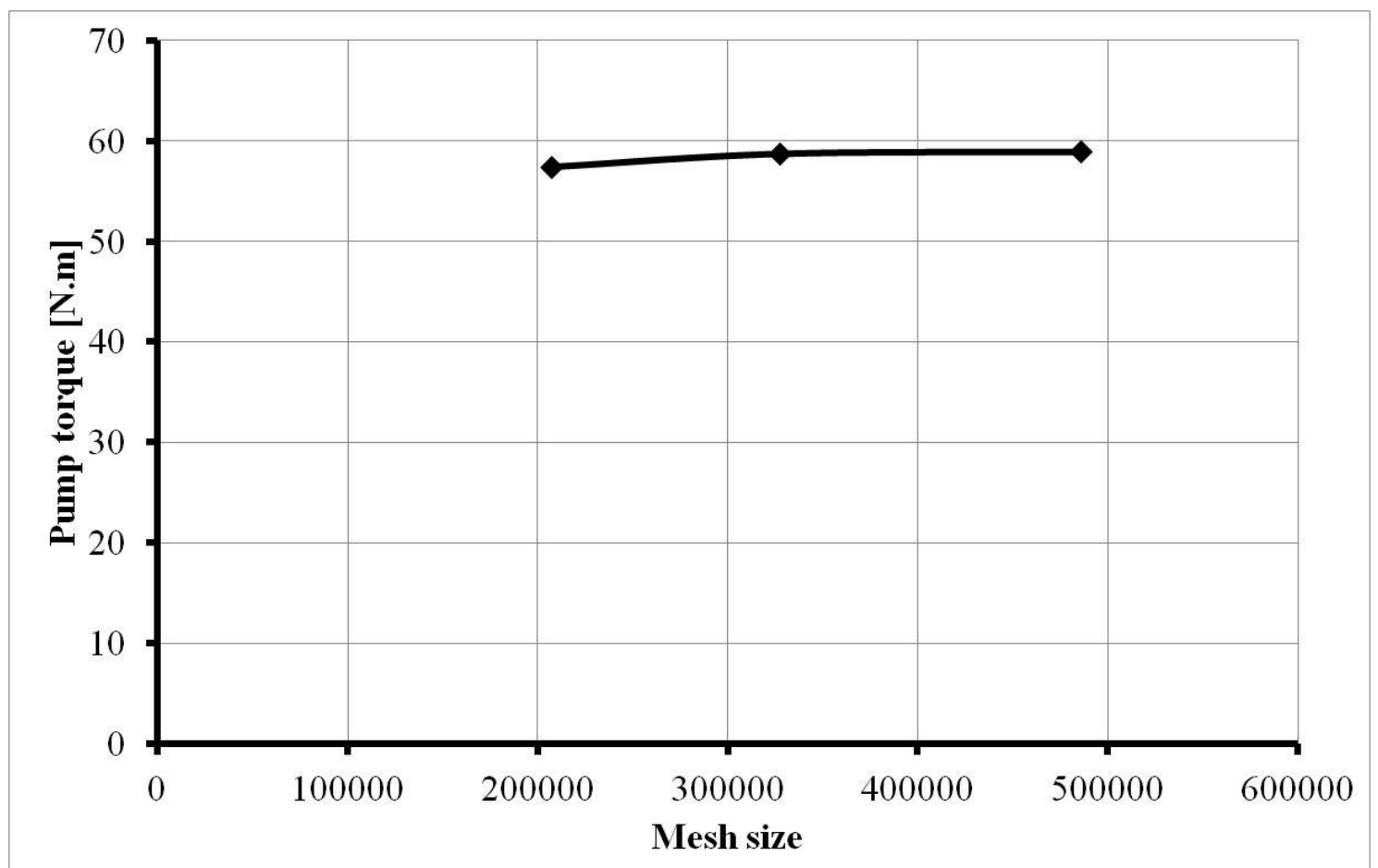

Figure 6: Pump torque for different grid size for (Allison-335) torque converter

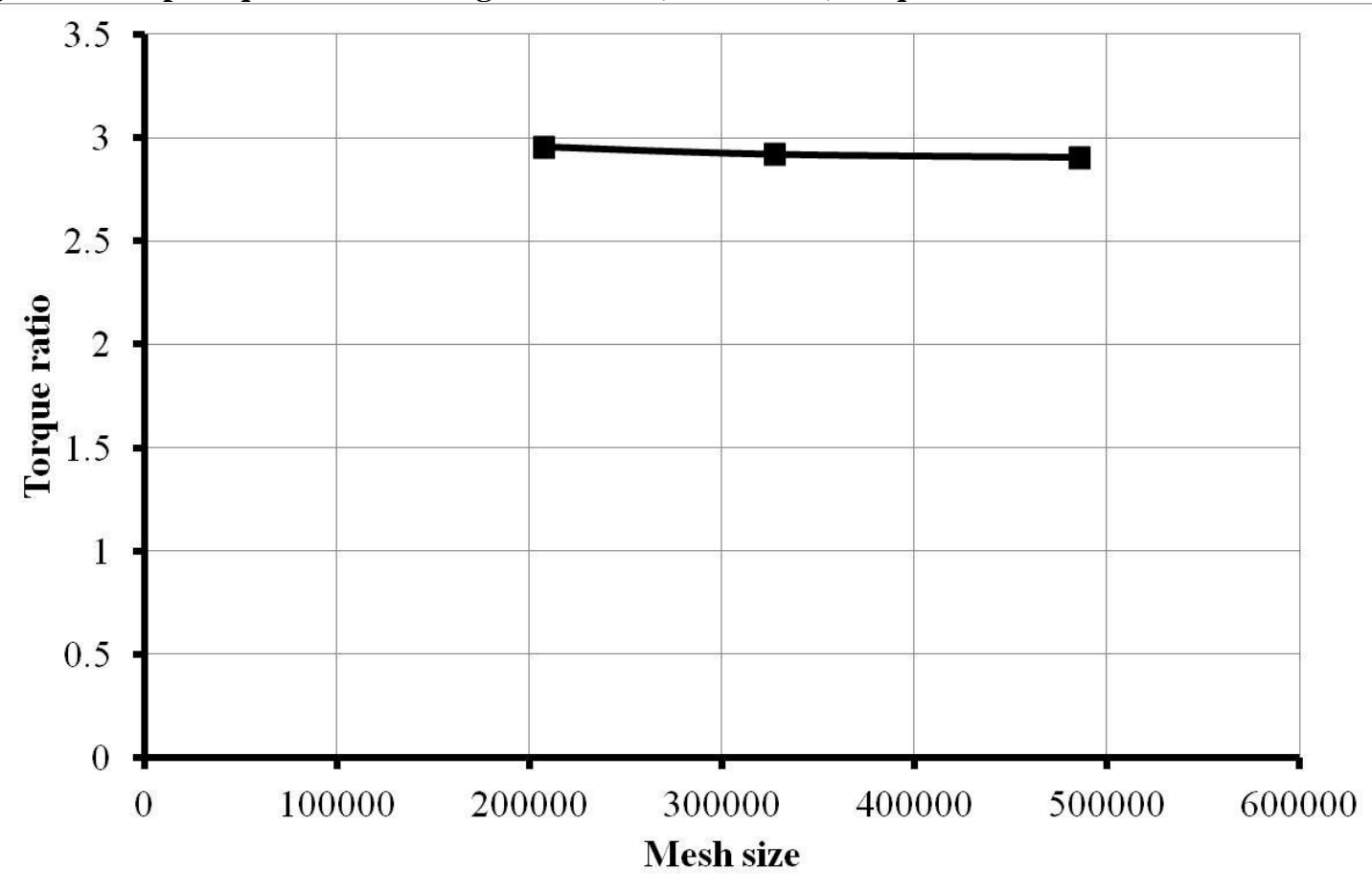

Figure 7: torque ratio for different grid size for Allison-335 torque converter 


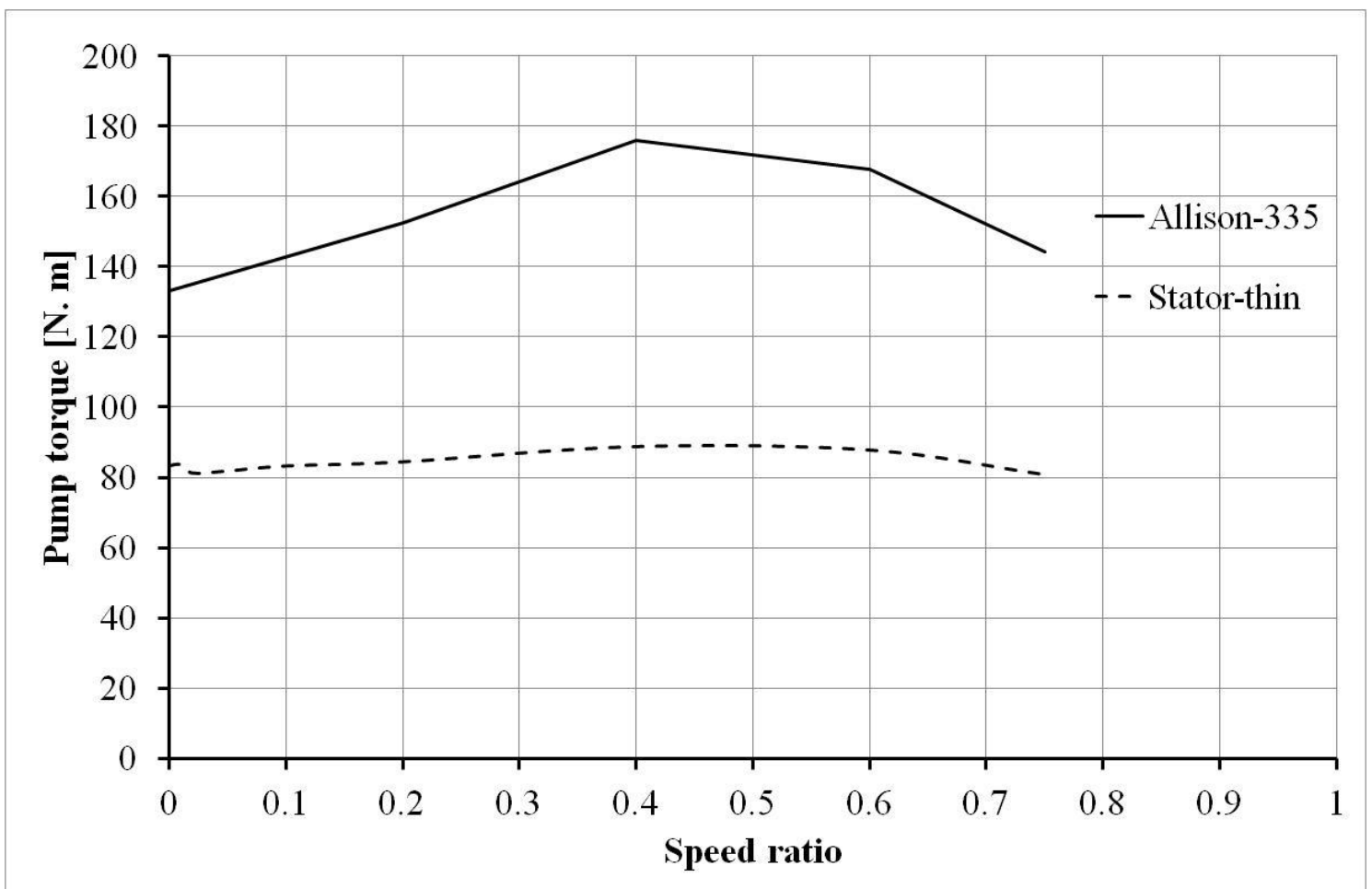

Figure 8: Pump torque against speed ratio for different stator shapes.

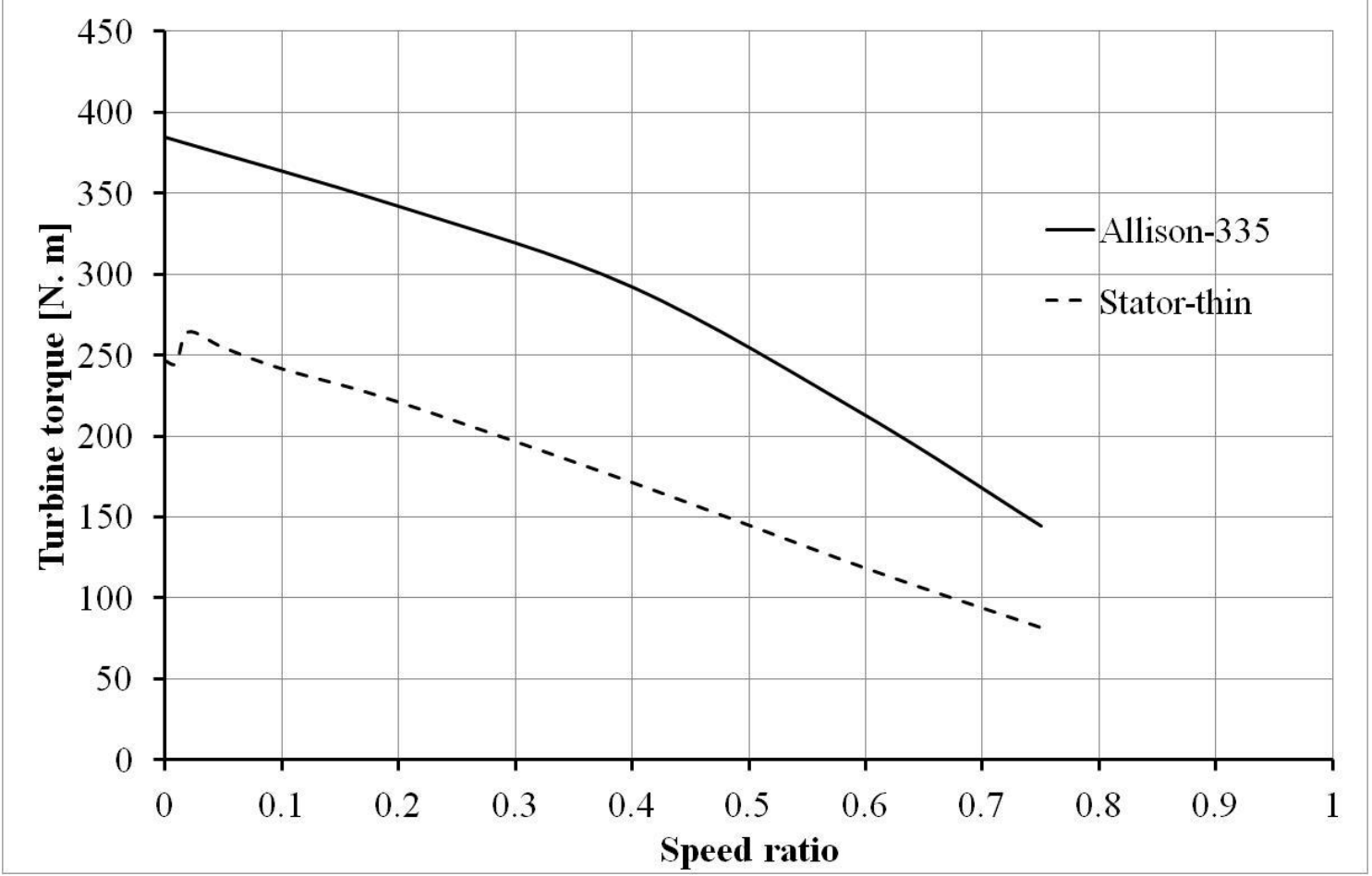

Figure 9: Turbine torque against speed ratio for different stator shapes. 


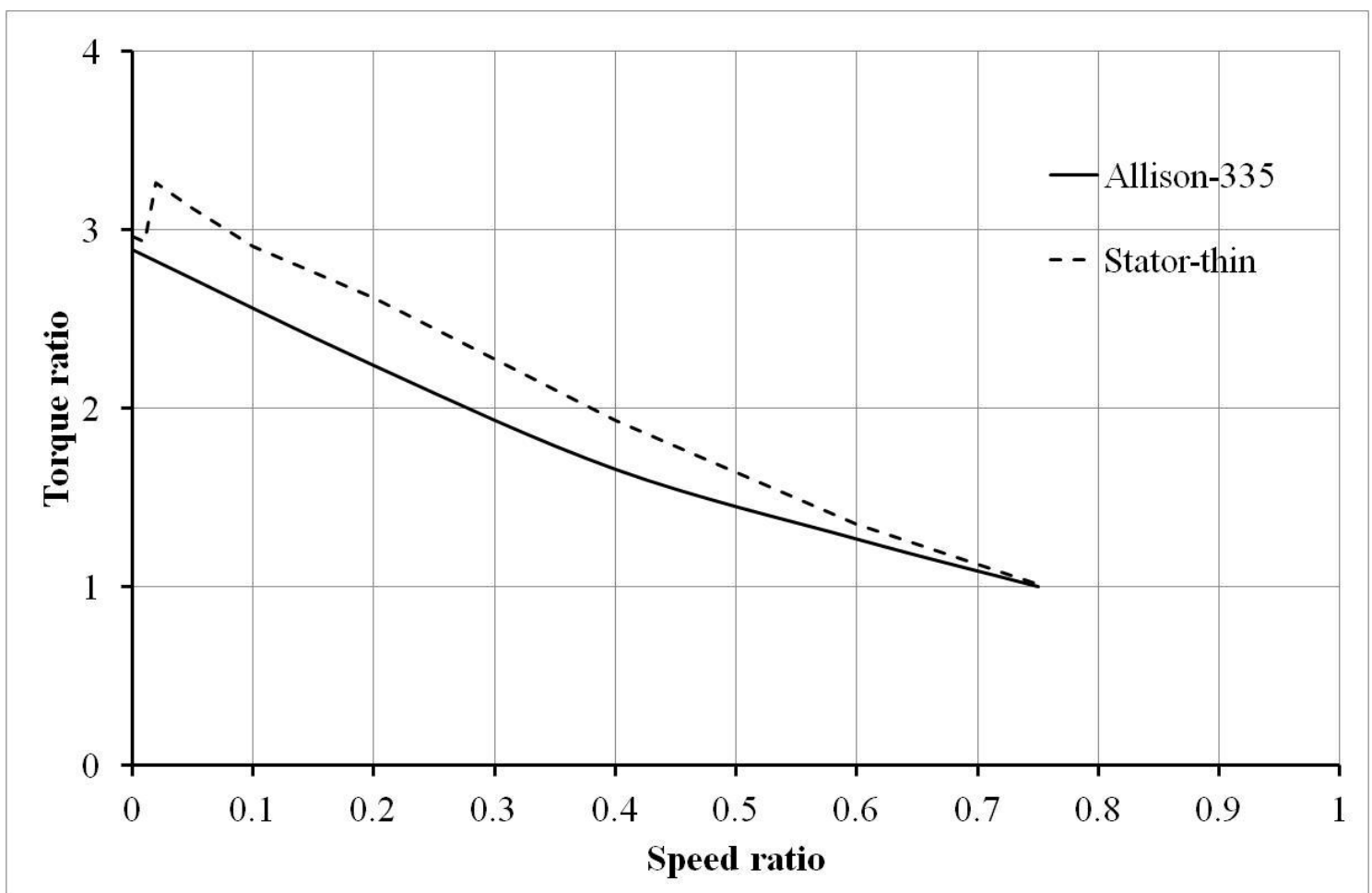

Figure 10: Torque ratio comparison for different stator shapes.

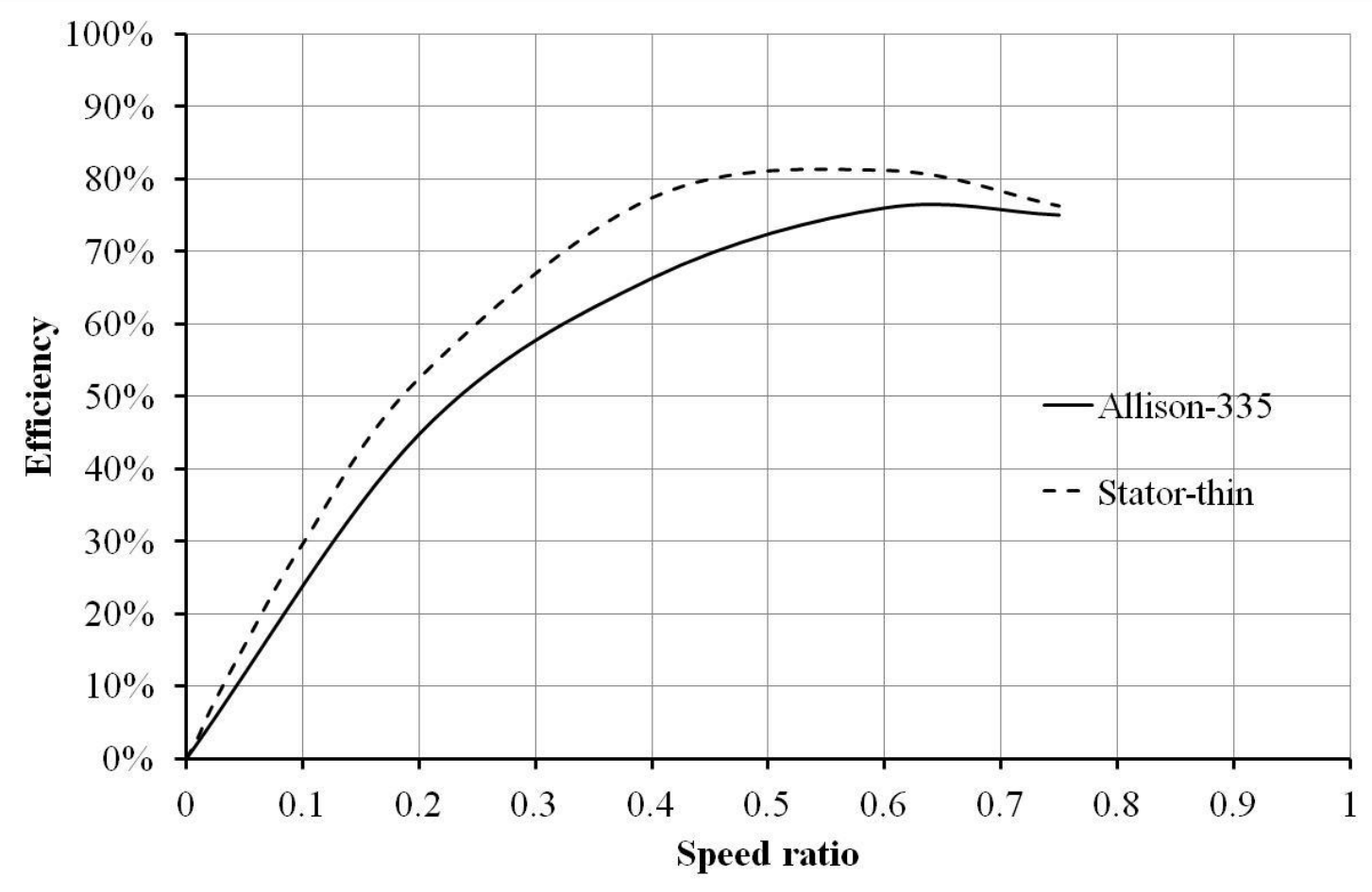

Figure 11: Efficiency comparison for different stator shapes. 


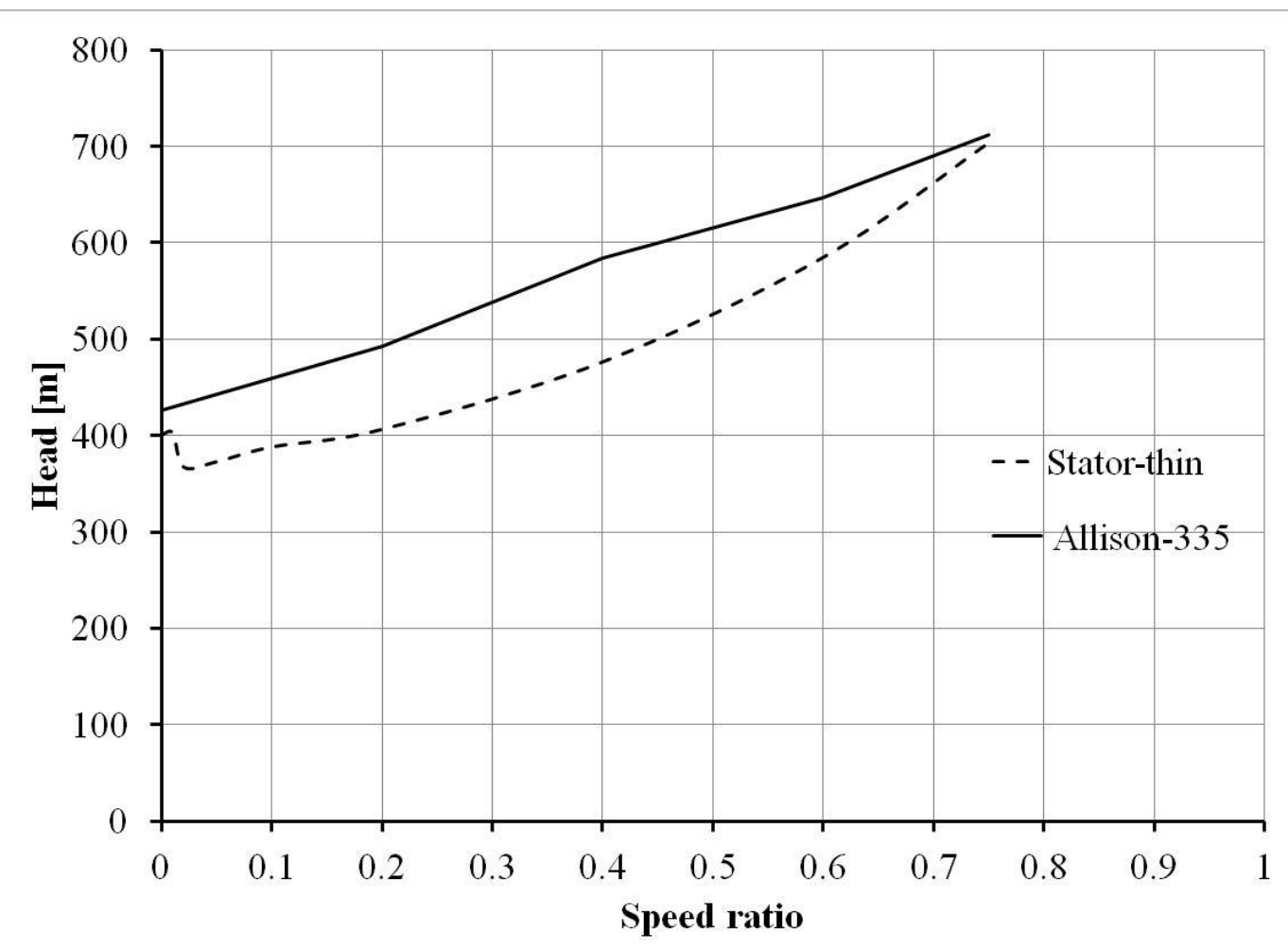

Figure 12: Pump head against speed ratio for different stator shapes.

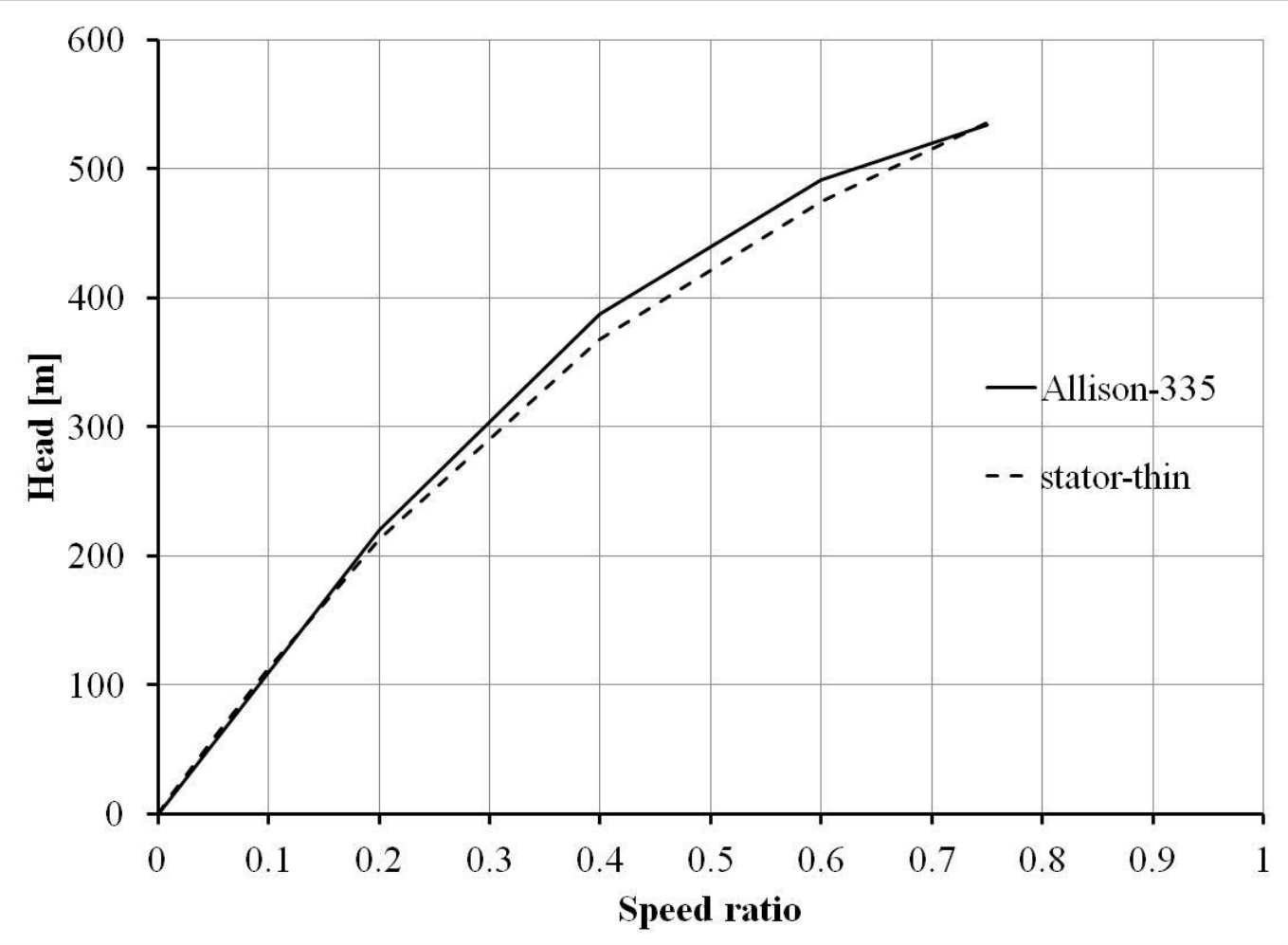

Figure 13: Turbine head against speed ratio for different stator shapes. 


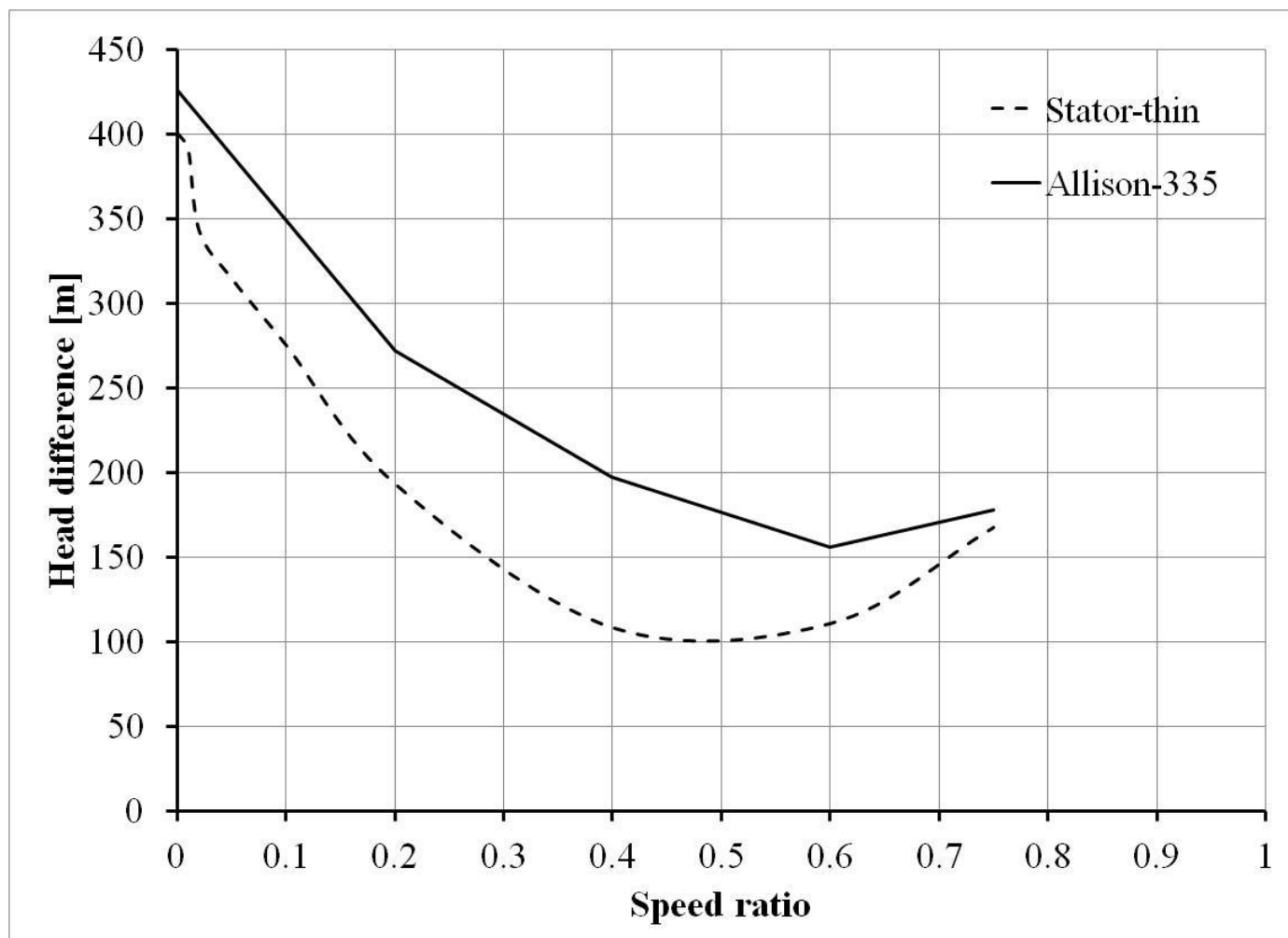

Figure 14: Head difference against speed ratio

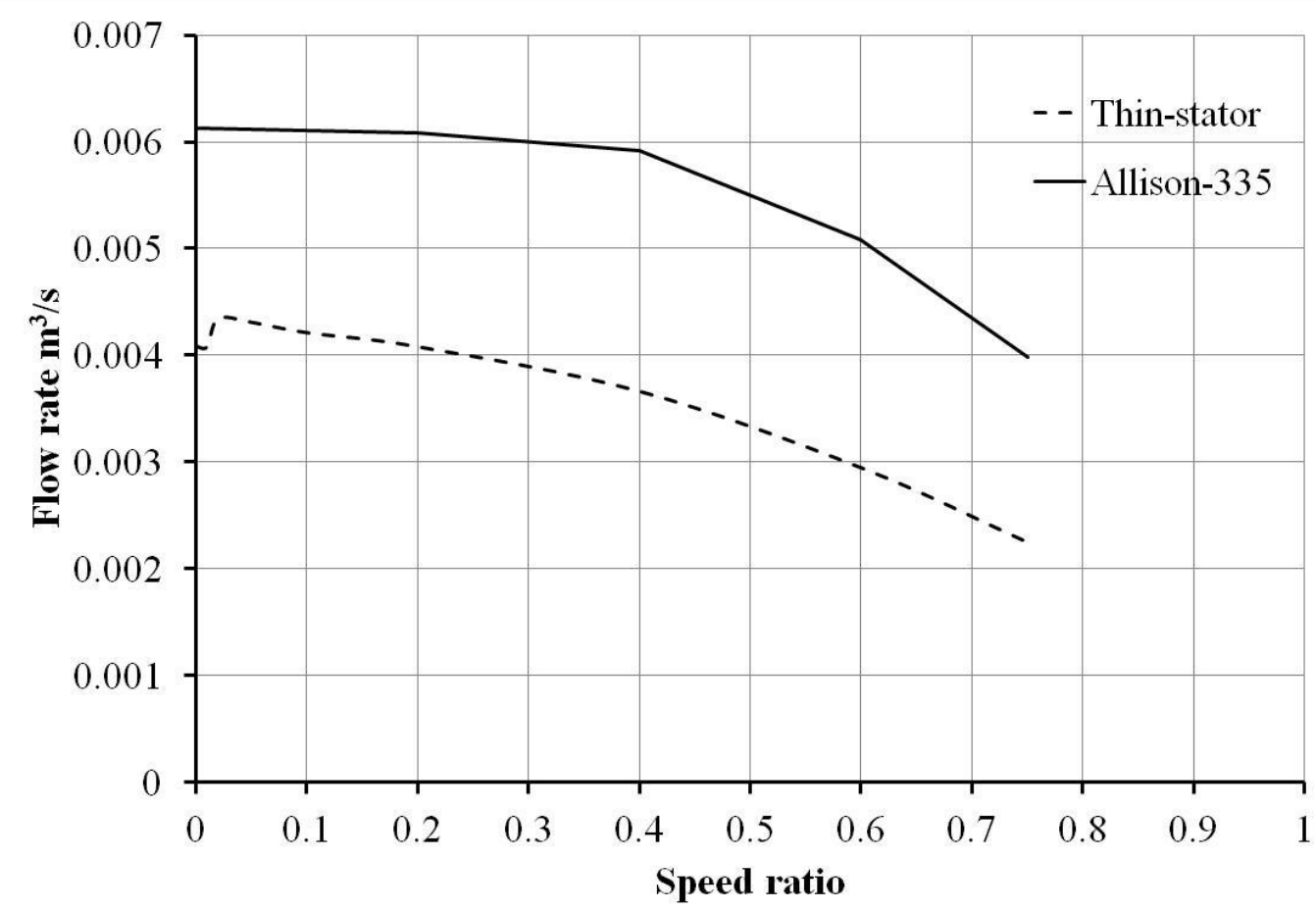

Figure 15: Flow rate across torque converters 


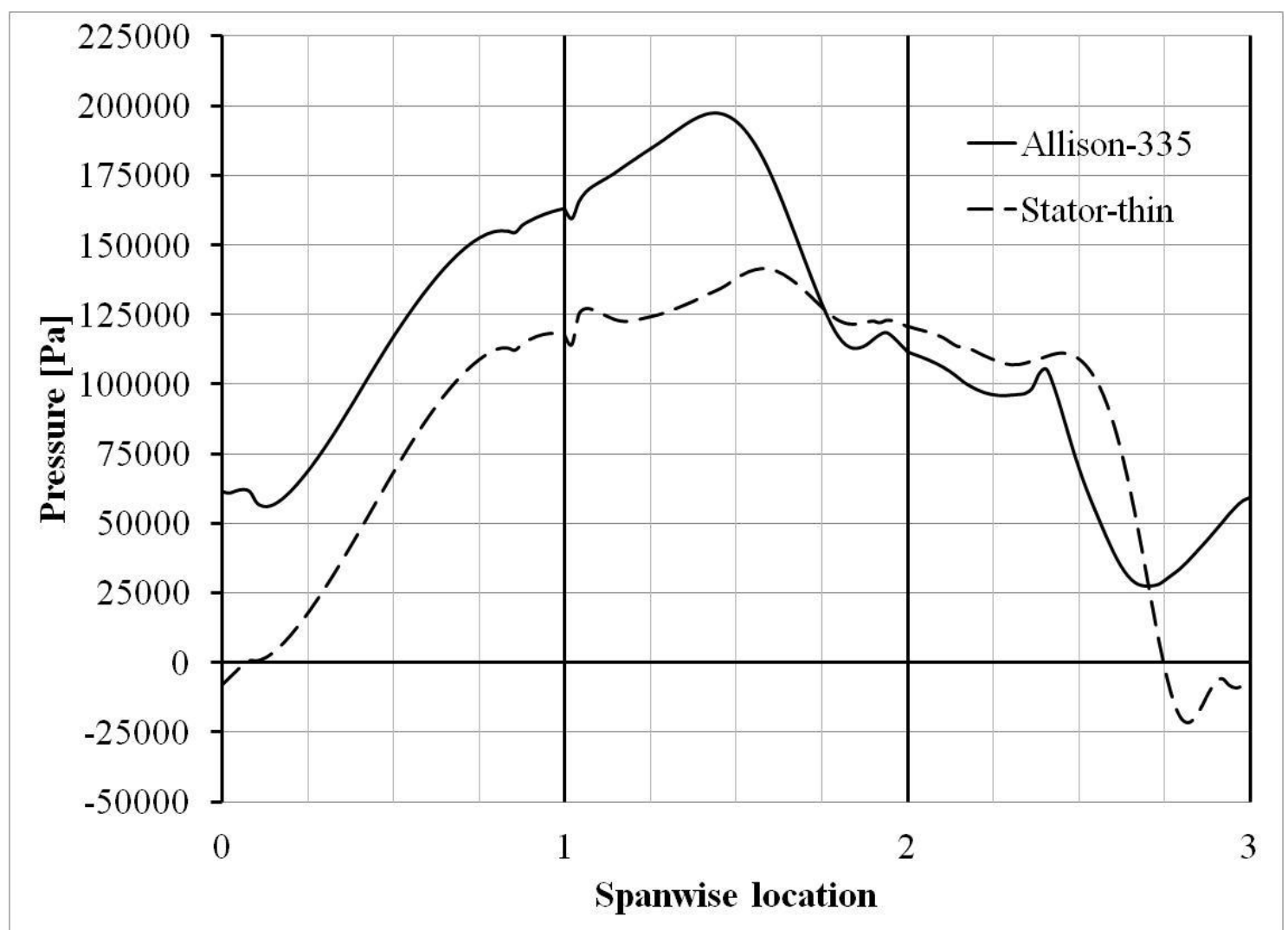

Figure 16: Pressure distribution along a streamline midway between hub and shroud inside the two torque converters with different stator blade shape at speed ratio 0.0

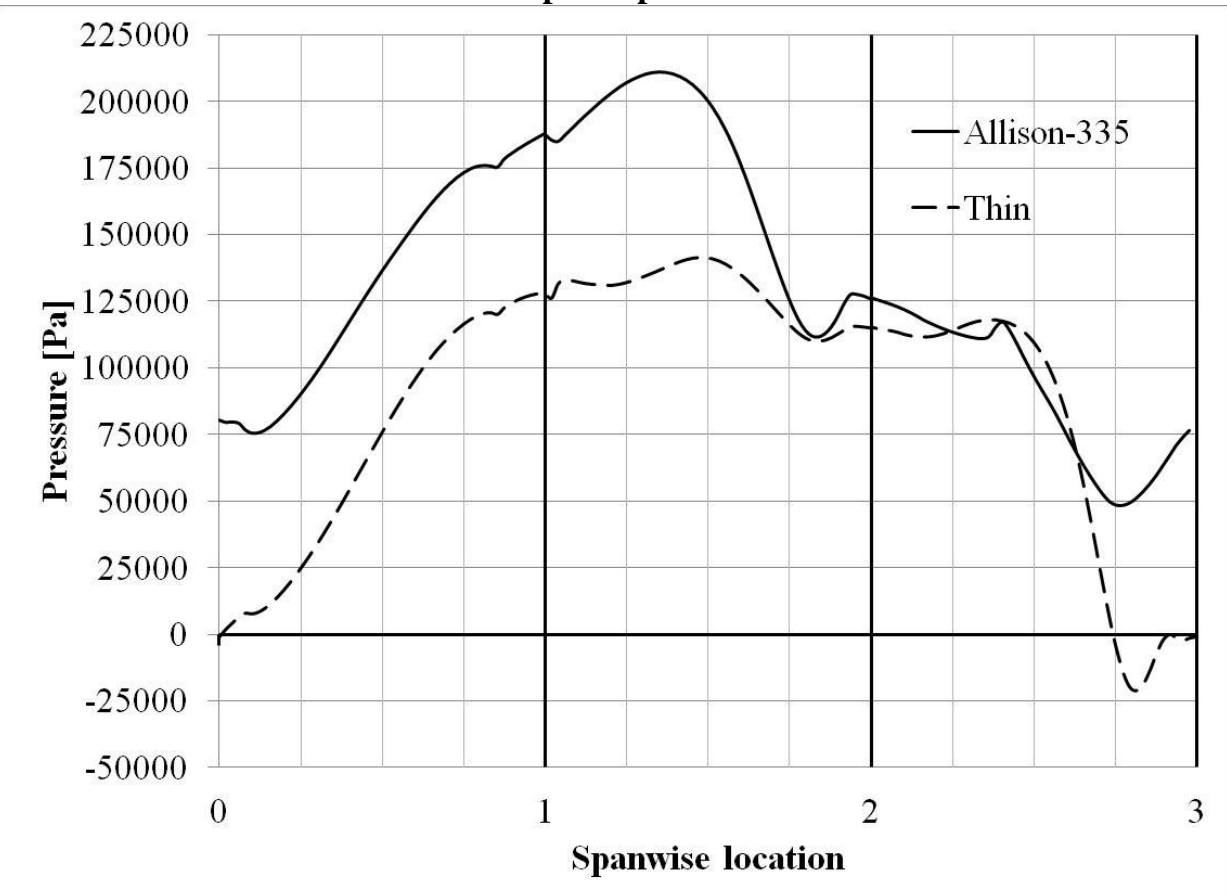

Figure 17: Pressure distribution along a streamline midway between hub and shroud inside the two torque converters with different stator blade shape at speed ratio 0.2 


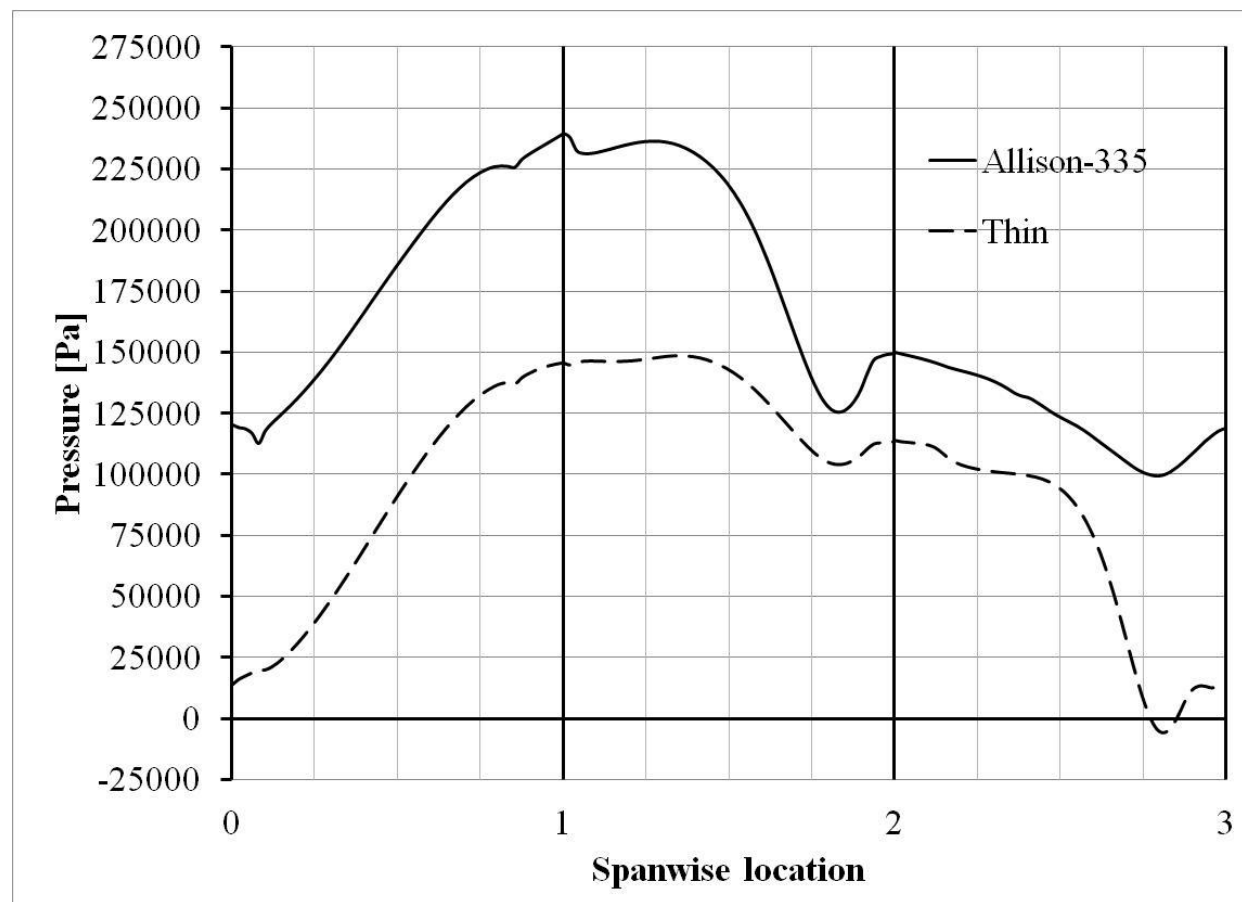

Figure 18: Pressure distribution along a streamline midway between hub and shroud inside the two torque converters with different stator blade shape at speed ratio 0.4

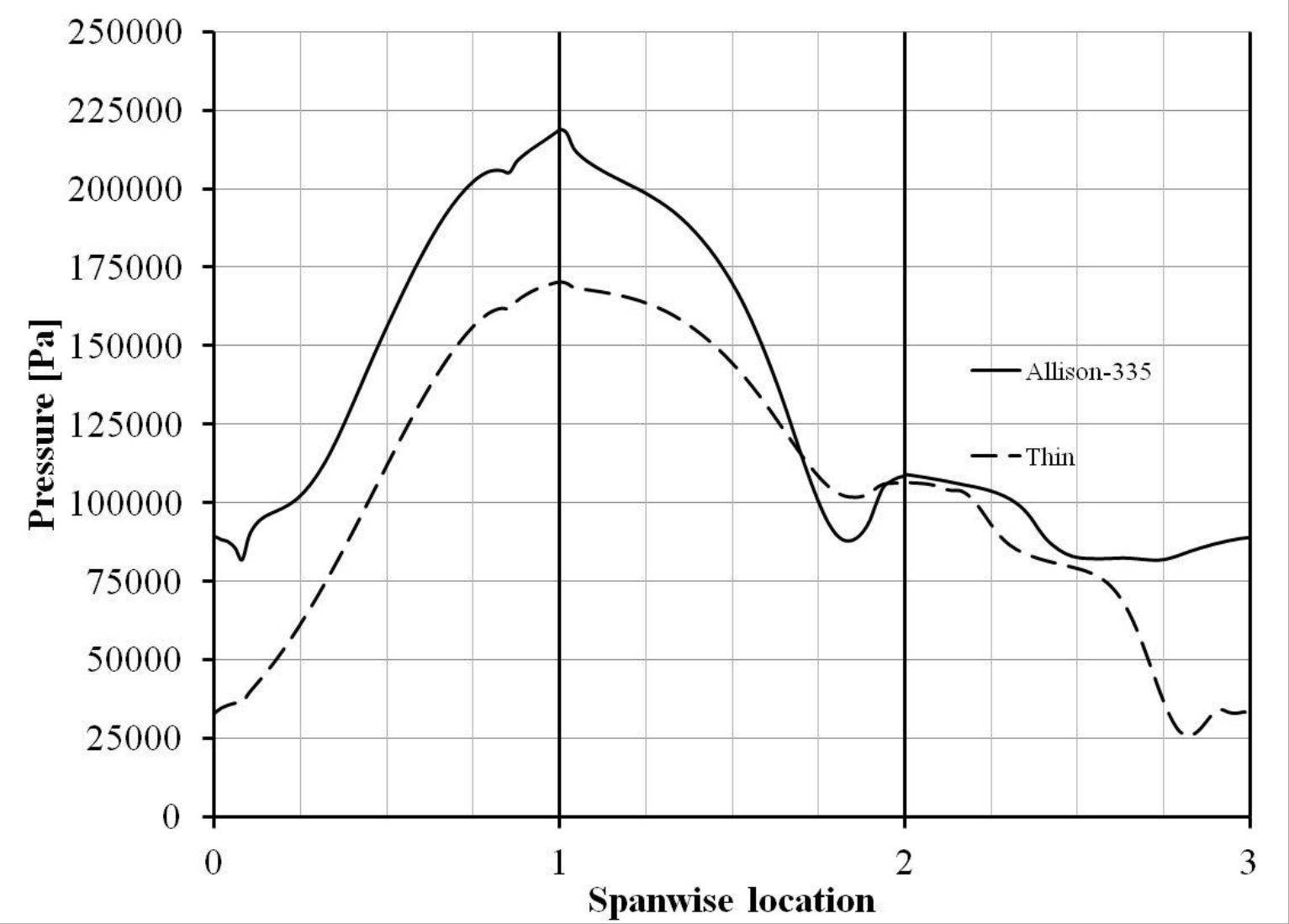

Figure 19: Pressure distribution along a streamline midway between hub and shroud inside the two torque converters at speed ratio 0.6 


\section{REFRENCES}

1. A. Khafagy, I.S., I. Elsherief, NUMERICAL STUDY ON THE EFFECTS OF NUMBER OF BLADES ON THE PERFORMANCE OF TORQUE CONVERTERS, in ASAT-16. 2015: Cairo, Egypt.

2. By, R.R. and B. Lakshminarayana, Measurement and Analysis of Static Pressure Field in a Torque Converter Pump. Journal of Fluids Engineering, 1995. 117(1): p. 109-115.

3. By, R.R. and B. Lakshminarayana, Measurement and Analysis of Static Pressure Field in a Torque Converter Turbine. Journal of Fluids Engineering, 1995. 117(3): p. 473478.

4. Brun, K. and R.D. Flack, Laser velocimeter measurements in the turbine of an automotive torque converter: Part I: Average measurements. Journal of turbomachinery, 1997. 119: p. 646-654.

5. Fujitani, K., R. Himeno, and M. Takagi, Computational Study on Flow through a Torque Converter. SAE Technical Paper 881746, 1988.

6. Abe, K., Kondoh, T., Fukumura, K., and Kojima, M., , Three-Dimensional Simulation of the Flow in a Torque Converter. SAE Technical Paper No. 910800, 1991.

7. By, R.R., B. Lakshminarayana, and R. Kunz, Navier-Stokes Analysis of the Pump Flow Field of an Automotive Torque Converter. Journal of Fluids Engineering, 1995. 117(1): p. 116-122.

8. Cigarini, M. and S. Jonnavithula, Fluid Flow in an Automotive Torque Converter: Comparison of Numerical Results with Measurements. SAE Technical Paper 950673, 1995.

9. Dale, M., Applied torque converters. Schilling, Jim (ed.), The Wisconsin engineer, 1957. 62(3): p. 18-23.

10. Schweitzer, J. and J. Gandham, Computational Fluid Dynamics in Torque Converters: Validation and Application. International Journal of Rotating Machinery, 2003. 9(6): p. 411-418. 